\title{
Correction to: Non-genetic risk and protective factors and biomarkers for neurological disorders: a meta-umbrella systematic review of umbrella reviews
}

\author{
Alexios-Fotios A. Mentis ${ }^{1 *}$, Efthimios Dardiotis ${ }^{2}$, Vasiliki Efthymiou ${ }^{3}$ and George P. Chrousos ${ }^{4}$
}

Correction to: BMC Med 19, 6 (2021)

https://doi.org/10.1186/s12916-020-01873-7

It was highlighted that the original article [1]contained an error under the section Principal findings specifically on page 12, the sentence "This systematic review of umbrella reviews revealed counterintuitively a significant association of low serum uric acid levels with a decreased risk of several neurological diseases" should read: "This systematic review of umbrella reviews revealed counterintuitely a significant association of high serum uric acid levels with a decreased risk of several neurological diseases". The original article has been updated.

\begin{abstract}
Author details
${ }^{1}$ Public Health Laboratories, Hellenic Pasteur Institute, Athens, Greece. ${ }^{2}$ Department of Neurology, University Hospital of Larissa, University of Thessaly, Larissa, Greece. ${ }^{3}$ University Research Institute of Maternal and Child Health and Precision Medicine, National and Kapodistrian University of Athens, Athens, Greece. ${ }^{4}$ University Research Institute of Maternal and Child Health and Precision Medicine, and UNESCO Chair on Adolescent Health

Care, National and Kapodistrian University of Athens, Athens, Greece.
\end{abstract}

Published online: 09 November 2021

\section{Reference}

1. Mentis AF, et al. Non-genetic risk and protective factors and biomarkers for neurological disorders: a meta-umbrella systematic review of umbrella reviews. BMC Med. 2021;19:6. https://doi.org/10.1186/s12916-020-01873-7.

The original article can be found online at https://doi.org/10.1186/s12916020-01873-7.

* Correspondence: amentis1@jhu.edu

${ }^{1}$ Public Health Laboratories, Hellenic Pasteur Institute, Athens, Greece

Full list of author information is available at the end of the article

C C The Author(s). 2021 Open Access This article is licensed under a Creative Commons Attribution 4.0 International License, which permits use, sharing, adaptation, distribution and reproduction in any medium or format, as long as you give appropriate credit to the original author(s) and the source, provide a link to the Creative Commons licence, and indicate if changes were made. The images or other third party material in this article are included in the article's Creative Commons licence, unless indicated otherwise in a credit line to the material. If material is not included in the article's Creative Commons licence and your intended use is not permitted by statutory regulation or exceeds the permitted use, you will need to obtain permission directly from the copyright holder. To view a copy of this licence, visit http://creativecommons.org/licenses/by/4.0/. The Creative Commons Public Domain Dedication waiver (http://creativecommons.org/publicdomain/zero/1.0/) applies to the data made available in this article, unless otherwise stated in a credit line to the data. 